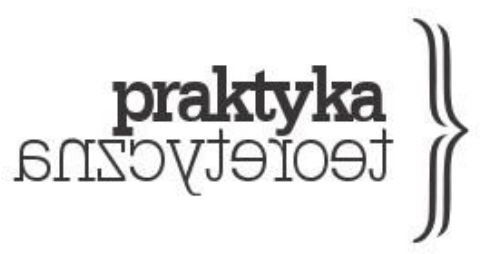

Praktyka Teoretyczna

Numer 1(31)/2019

ISSN 2081-8130

DOI: $10.14746 /$ prt.2019.1.7 www.praktykateoretyczna.pl

\title{
REPORT FROM BEYOND THE EVENT HORIZON
}

JOANNA BEDNAREK

\begin{abstract}
This is a review essay discussing Magdalena Grabowska's book: Zerwana genealogia: Driałalność społeczna i polityczna kobiet po 1945 roku a wspótczesny polski ruch kobiecy (Warszawa: Wydawnictwo Naukowe SCHOLAR, 2018).
\end{abstract}

Keywords: feminism, Polish People's Republic, Women's League 
Despite thirty years having passed since the fall of the Polish People's Republic, we are still far from perceiving these times just as past. It would even seem that the farther we are from this moment in history, the denser the web of phantasms enveloping the facts, and sometimes (as in the case of conservative historical policy) the phantasms overtake the facts themselves more and more. The distortion of the history of the people, whether activists or "normal people", who co-created the previous regime, adapted to it, or rebelled against it, by the right, the hegemonic force in Poland nowadays, is undeniably a cause for concern; also concerning is that the "progressive" movements are not necessarily invested in creating counter-hegemony. Moreover, this is not caused by a lack of thorough historical analysis - there was plenty of it, for example, in the "W krainie PRL" published by Wydawnictwo Trio - but by a lack of representation of their message in the public imagination. For feminist-activists or female literature researchers, PRL (the Polish abbreviation for the Polish People's Republic) remains “a legacy of the void” (Araszkiewicz 2014), "a black hole”, “a freezer", “a rift”, (Grabowska 2018, 51, 62). To sum up, we know everything about these times because there is not much to know - those were the times of martyrdom, of nothing of note; hence it is not worth it to take an interest in these times.

This is clearly untrue - in the 1960s and 1970s there were writers such as Jadwiga Żylińska (Marzec 2014; see also: Iwasiów and Galant 2011) or Barbara Czałczyńska (Bednarek 2015), artists like Maria Pinińska-Bereś, Natalia LL, or Ewa Partum (Majewska 2017; Toniak 2015), who represented, or rather pioneered, the feminist perspective in Poland. The abovementioned approach, however, allows them to be dismissed as exceptions, anomalies, unable to challenge a vision of PRL as a realm beyond the event horizon, of which nothing can be said, or, to be exact, where you have no access, and from which you can't return to give a description. Unlike a cosmological black hole, the black hole of PRL is conditioned by human cultural constructs; furthermore, it is an arbitrary and artificial phenomenon, curtailing our ability to understand the recent past that shaped us.

Fortunately, young researchers show us how to look into the black hole; besides the aforementioned series of books (e.g. Sadowska 2010; Wóycicka 2009; Nowakowska and Wóycicka 2010; Borodziej and Kochanowski 2010) in the past few years there have been books on the female role in socialist modernisation (Fidelis 2010), on the discourse on sexuality in PRL (Kościańska 2015) or the figures of female communists, and the prejudices and phantasms associated with them (Mrozik 2013, 2016; Zawadzka 2016; Forecki 2017; Bukalska 2016). We have also seen an analysis of referring to PRL as a black hole, characteristic of the Polish feminist movement's narration (Mrozik 2014; Zawadzka 2017). This mechanism of representation is perceived as a symptom of the conservatism of the movement, and it is a capitulation to right-wing historical policy, as well as its attachment to an older, posttransitional liberal tendency of demonising communism. 
The book by Magdalena Grabowska is not only a recent development of this tendency, but also represents a new quality in the debate on PRL's significance for our times and the genealogy of Polish feminism. It is an account of the lives of a few women, who were members of female communist organisations, based on a few dozen in-depth interviews, and on an analysis of materials from Archiwum Akt Nowych (New Acts Archive). The author herself stresses that her work represents a "revisionist" approach to communist history; while the hegemonic approach, both in post-communist and Western countries, assumes the conceptualisation of "the periods before and after communism as opposing and separate state, political and institutional systems", the revisionist approach "offers an analysis focused on highlighting connections and relations between various conceptualisations of gender equality, and on practices of action in the name of equality extant during the communist period and during the transition" (Grabowska 2018, 15). This approach manifests in two ways.

Firstly, the dominant approach assumed that women, unless they were activists, i.e. unless they were on the "oppressor's" side, were devoid of agency; they had to be victims or passive objects of historical changes. The interviews conducted by Grabowska and analysis of archival materials show us a different picture. We get to know, for example, the various motives of people who decided to join the Women's League, like willingness to pursue a career, to achieve positive outcomes for women, or faith in the advantages of the socialist modernisation project (Grabowska 2018, 124-136). "We have pressed for the organisation of nurseries and kindergartens within factories. For factory canteens. It has been a huge blessing for women since there have been problems with supplies" (Grabowska 2018, 138).

We also get to familiarize ourselves with the controversies during the assemblies of the Women's Department of PPR (Polish Worker's Party) and PZPR (Polish United Worker's Party) during the years 1946-1952, during the times when it would seem that the realisation of a gender equality project in post-war Poland would come about because of ideological communists, and it still was not settled what form should it take (Grabowska 2008, 191-202); we become acquainted with a subsequent period of "practical activism", when the Women's League and Household Institute gave up on the reconstruction of gender relations and introduced a pragmatic strategy of making life easier for women working "double shifts". Members of these organisations surely operated under the conditions dictated by an authoritarian regime - however, denying their agency, perceiving them as victims of manipulation or as cynical because of this, would be a mistake. This perception of women's actions in communist states is frequently caused by a particular vision of agency as genuine autonomy, an action unconditioned by society, politics or history. This is, as Grabowska argues, not only ideologically motivated - it stems from the liberal vision of an individual as independent from the society in which they live - but also simply untrue, since it makes impossible an examination of real women's choices and the forces that affected these choices. 
Even in "democratic" countries, women remain under the pressure of manifold formal and informal requirements such as the necessity of doing waged and unwaged work or negotiating with "the beauty myth" (Wolf 2014). Using a notion of agency as webbed in concrete social conditions enables the sketching of a map of freedom and servitude particular to each context.

Secondly, the overview of the changes taking place in PRL's gender policy provided above shows that communism did not impose emancipation on Polish women, for which they and the whole society were not ready. Although PRL brought professional activation of women, changes in "the sexual contract" (Pateman 2014), i.e. an unwritten agreement defining gender roles and relations between men and women in a given society, went only so far as was necessary from the standpoint of post-war modernisation. After a few years of Stalinism, when the policy of encouraging women to perform "male" professions was implemented, and activists in women's organisations were thinking about the women issue in the largest possible categories, perceiving their activity as a broad emancipation project connected with the politicization of the female masses and propagating communism among them, the movement shifted towards de-politicization (Grabowska 2018, 78-79, see Fidelis 2010, 18-21). This shift was caused by the reluctance towards this policy of both ordinary women and the activists of the League of Women, who focused instead on social activity. Already in the 1950s, the years of Stalinism were considered an aberration - many of the anti-Communist clichés we use today, like the figure of women tractor drivers, we inherited from PRL.

Already at the end of the 1940s and early 1950s, the tendency towards depoliticisation was evident in the Polish women's movement. Activists essential for the development of the women's movement lost their positions, and the communist leaders were pushed, among others as part of the anti-Semitic campaign initiated in the Stalinist period, to less prominent party and institutional positions (Grabowska 2018, 79, see 18).

It turns out that the lines of continuity and rupture occur in other places than anticommunist dogma has accustomed us to think they were; many images and attitudes that are antipathetic to communism, which is today our phantasmatic baggage, arose in the period of the People's Republic of Poland. The era of real socialism was also not a monolith: organisations, institutions and individuals had their own goals and were subject to multiple pressures, which led to tensions, conflicts, and political changes (Kenney 2015).

The aim of Grabowska's work, however, is not only to challenge stereotypes and show the transformation of the equality narrative within the PRL (Grabowska 2018, 18) but also, perhaps above all, to intervene in the identity narratives of Polish feminism. This movement associated its origins with the opposition of the 1980s, Solidarity, and political transformation (Kondratowicz 2013; Penn 2014; Graff 2003), and also identified itself in relation to the categories or periodisation developed within the Western feminist movement. As Grabowska 
writes, the horizon of the debate on the women's movement in Poland is determined by three narratives:

[T] he narrative of lack, conceptualising East European feminism as non-existent, a convergent narrative representing women's movements in post-socialism as delayed in comparison with the West and, the narrative bringing them together, (...) anticommunist narrative, which portrays communism as responsible for the non-existence and/or delays of emancipation movements in Poland (Grabowska 2018, 19).

Feminism defined itself in opposition to communism as a figure of absence and delay, and at the same time as an imitative movement towards the West, and more specifically the United States; it was, as Grabowska points out, somewhat inevitable - after the transformation, the feminist movement had to win for itself a place on the political scene defined by the hegemony of enthusiastic liberalism and the offensive of conservatism. In hindsight, however, this approach was an ideal recipe for self-colonisation - Polish feminism set itself in the position of an inferior sister of Western feminism, recreating the stereotypical approach of Central and Eastern Europe as a "half-orient" (Grabowska 2018, 41) which must learn about emancipation from Westerners, and also deny part of its history - "the local legacy of emancipation" (Grabowska 2018, 26). “Escape of feminism from 'ideology' was supposed to be a strategy of survival, its by-product was to erase from the history of the women's movement that part of it that has common roots with communism, and often also with socialism" (Grabowska 2018, 45).

Thus, Grabowska's work is an attempt at both decolonisation and genealogy. Its empirical dimension, i.e. interviews and analysis of archival materials, is shaped by bold theoretical assumptions: the author's aim is to write, in the words of Foucault, the "history of the present" (Grabowska 2018, 22), showing what forces, explicit and implicit, recognized and unrecognized, created the Polish women's movement. It is about showing the border of a feminist archive, the boundary of "what can be said in the context of the narrative about the history of the women's movement in Poland" (Grabowska 2018, 173). The story of the activities of ideological communists such as Edwarda Orłowska, Eugenia Pragierowa and Żanna Kormanowa, with all the accompanying ambivalence, as well as the activities of the "second generation" pragmatic activists of the Women's League, not only fills the gap in knowledge, but also reorganizes the story of Polish feminism, supplementing it with the repressed communist presence and showing that we have a local tradition of emancipation although it is marked by ambivalence, complicated, and does not fit into the pattern of struggle between good and evil. Thanks to this, it becomes possible to decolonise the narrative about feminism in Eastern Europe (Grabowska 2018, 55). 
Why is it so important? As Grabowska argues, the domination of the narrative of lack, backwardness and anti-communism has resulted in:

Feminism, which forgets about its genealogies, telling an unconvincing story, from the point of view of feminist practice, the history of emancipation and women's awareness, about the lack of equality tradition in Poland. A movement that joins historical narratives of Western feminisms, a movement whose vision of one's own (individual or collective) identity is largely elitist and unconvincing (Grabowska 2018, 173).

These are strong words - but, I think, not too strong. Anticommunism, although it was an unavoidable part of the feminist strategy in the 1990s, hurt the movement very much, imposing a liberal curse on it: insensitivity to class issues and more generally systemic mechanisms of oppression. Today, when the horizon of our thinking and action is no longer defined by transformation, it is worth fixing it. Feminism in general, not only socialist feminism, needs communism and communists. 


\section{References}

Araszkiewicz, Agata. 2014. Zapomniana rewolucja: Rozkwit kobiecego pisania w dwudziestoleciu miedzywojennym. Warszawa: Instytut Badań Literackich PAN.

Aron, Jacob. 2014. "Stephen Hawking's new theory offers black hole escape”. New Scientist online. https://www.newscientist.com/article/dn24937-stephen-hawkings-new-theoryoffers-black-hole-escape/.

Bednarek, Magdalena. 2015. "Nic, które łączy kobiety: O prozie Barbary Czałczyńskiej”. In Twórczość niepozorna: Szkice o literaturze, ed. Joanna Grądziel-Wójcik, Agnieszka Kwiatkowska and Lucyna Marzec. Kraków: Pasaże.

Borodziej, Włodzimierz and Jerzy Kochanowski (eds.). 2010. Bocznymi drogami: Nieoficjalne kontakty spoleczeństw socjalistycznych 1956-1989. Warszawa: Wydawnictwo Trio- Instytut Historyczny Uniwersytetu Warszawskiego.

Bukalska, Patrycja. 2016. Krwawa Luna. Warszawa: Wielka Litera.

Forecki, Piotr. 2017. "Fantazmat Julii Brystygier". Środkowoeuropejskie Studia Polityczne 1: 47-69.

Grabowska, Magdalena. 2018. Zerwana genealogia: Driatalność spoteczna i polityczna kobiet po 1945 roku a wspótczesny polski ruch kobiecy. Warszawa: Wydawnictwo Naukowe SCHOLAR.

Graff, Agnieszka. 2003. "Lost between the waves? The paradoxes of feminist chronology and activism in contemporary Poland". Journal of International Women's Studies 4(2): 100-116.

Fidelis, Małgorzata. 2010. Kobiety, komunizm i industrializacja w powojennej Polsce. Trans. Maria Jaszczurowska. Warszawa: W.A.B.

Hawking, Stephen. 2014. "Information Preservation and Weather Forecasting for Black Holes”. High Energy Physics - Theory. https://arxiv.org/abs/1401.5761.

Iwasiów, Inga and Arleta Galant (eds.). 2011. Pisarstwo kobiet pomiędzy dwoma dwudriestoleciami. Kraków: Universitas.

Kenney, Padraic. 2015. Budowanie Polski Ludowej: Robotnicy a komuniści 1945-1950. Trans. Anna Dzierzgowska. Warszawa: W.A.B.

Kondratowicz, Ewa. 2013. Być jak narodowy sztandar: Kobiety i Solidarność. Warszawa: Wydawnictwo Naukowe SCHOLAR.

Kościańska, Agnieszka. 2015. Pteć, prazyjemność i prz̨emoc: Ksq̨tałtowanie wiedzy eksperckiej o seksualności w Polsce. Warszawa: Wydawnictwo Uniwersytetu Warszawskiego.

Majewska, Ewa. 2017. Tramwaj z̧wany uznaniem. Warszawa: Instytut Wydawniczy Książka i Prasa.

Marzec, Lucyna. 2014. Po kadzৃieli: Feministycžne pisarstwo Jadwigi Żylińskiej. Poznań: Wydawnictwo Nauka i Innowacje.

Mrozik, Agnieszka. 2013. “»Komuniści (nie) mają ojczyzny...« Wanda Wasilewska jako polska (anty)bohaterka narodowa”. Studia Litteraria et Historica 2: 528-554.

Mrozik, Agnieszka. 2014. "Poza nawiasem historii (kobiet), czyli po co nam dziś komunistki". Wakat On-line 3. 
Mrozik, Agnieszka. 2016. "Nieobecne, ale użyteczne. O pożytkach z komunistek w polskim dyskursie publicznym po 1989 roku”. In Sporne postaci polskiej krytyki feministycznej, ed. Monika Świerkosz. Gdańsk: Wydawnictwo Naukowe Katedra.

Nowakowska, Agnieszka and Zofia Wóycicka. 2010. Etniçna polityka komunistów: Dwa casusy. Warszawa: Wydawnictwo Trio.

Pateman, Carole. 2014. Kontrakt plci. Trans. Jarosław Mikos. Warszawa: Czarna Owca.

Penn, Shana. 2014. Sekret Solidarności. Trans. Maciej Antosiewicz. Warszawa: W.A.B.

Sadowska, Joanna. 2010. Sercem i myśla zuiqzani z Partiq: Zwiqzek Mtodzieży Socjalistycznej (19571976): polityczne aspekty dziatalności. Warszawa: Wydawnictwo Trio.

Toniak, Ewa (ed.). 2015. 3 kobiety: Maria Pinińska-Bereś, Natalia LL, Ewa Partum. Warszawa: Narodowa Galeria Sztuki Zachęta.

Wolf, Naomi. 2014. Mit urody. Trans. Monika Rogowska-Stangret. Warszawa: Czarna Owca.

Wóycicka, Zofia. 2009. Przerwana żatoba: Polskie spory wokót pamięci nazistowskich obozón koncentracyjnych $i$ zagłady 1944-1950. Warszawa: Wydawnictwo Trio.

Zawadzka. Anna. 2016. "Piętno »żydokomuny« w ujęciu pokoleniowym: Szkic do badań". Teksty Drugie 1: 88-107.

Zawadzka, Anna. 2017. "Polityka mimikry: Polityka historyczna i feminizm w Polsce". Zadra $1-2$. 
Joanna Bednarek - philosopher, translator, writer, member of the editorial collective of Praktyka Teoretyczna. She published in Teksty Drugie, Krytyka Polityczna and Czas Kultury.

\section{ADDRESS:}

Praktyka Teoretyczna

ul. Szamarzewskiego 89c

60-568 Poznań, Poland

EMAIL: bednarekjoanna87@gmail.com

Citation: Bednarek, Joanna 2019. "Report From Beyond the Event Horizon” Praktyka Teoretycæna 1(31): 147-155

DOI: $10.14746 /$ prt.2019.1.7

AuTOR: Joanna Bednarek

TYTUL: Raport zza horyzontu zdarzeń

ABSTRAKT: Prezentowany tekst to esej recenzyjny na temat książki Magdaleny Grabowskiej, Zerwana genealogia: Działalność społeczna i polityczna kobiet po 1945 roku a współczesny polski ruch kobiecy (Warszawa: Wydawnictwo Naukowe SCHOLAR, 2018).

SŁOWA KLUCzowE: feminizm, Polska Rzeczpospolita Ludowa, Liga Kobiet 